\title{
Green Supply Chain Management Practices by Superstores in Bangladesh: A Case Study in Dhaka
}

\author{
Zahir Raihan Salim* \\ Senior Lecturer, College of Business Administration, \\ International University of Business Agriculture and Technology (IUBAT), Bangladesh \\ Md. Mortuza Ahmmed \\ Assistant Professor, Department of Mathematics, \\ American International University - Bangladesh (AIUB), Bangladesh \\ Md. Shahadat Hossain \\ Operation Executive, Daraz Group Bangladesh \\ Abu Syef Md Tusar \\ Operation Executive ,Daraz Group Bangladesh
}

\begin{abstract}
Green Supply Chain Management has emerged as a comparatively newfangled area of supply chain management in Bangladesh. Implementation of green supply chain management practices has been directed by the everincreasing demand of protection of the environment in various sectors across the country, especially in the capital Dhaka. Several business institutions are dealing with the issue of sustainability in the supply chain by employing green Supply Chain Management .The study analyzes various green logistics practices implemented by different superstores in Dhaka. Primary data were collected through a pre-assigned questionnaire which included questions towards the respondents regarding green logistics practices employed. The respondents of the study were the branch or outlet managers or their counterpart in various superstores in Dhaka. The sample size of the study was 90 drawn randomly from different locations in Dhaka. Data were analyzed applying Pearson's correlation coefficient, test of significance etc. via SPSS (Statistical Package for Social Science). Significance was determined with $p$-value $\leq 0.01$. Findings of the study revealed highly significant correlation between arrangement of seminar and workshop with management of greening and tree plantation. One limitation of the study was the fact that some of the respondents were a bit diffident to give enough time as the superstores were going through busy schedules most of the time.
\end{abstract}

Keywords: Supply chain management, Pearson's correlation coefficient, test of significance.

DOI: $10.7176 / \mathrm{EJBM} / 11-16-08$

Publication date:June $30^{\text {th }} 2019$

\section{Introduction:}

Supply Chain Management infers to a scale of management and control over consignment activities that contemporary technology has transported into being. It has emerged as one of the most significant advances in the retail industry. Greenness is something that includes an extensive range of environmental trepidations employed to recommend harmonization with the environment. If we put together the two words 'logistics' and 'green', it would suggest an environmentally-friendly and effectual supply chain management system (Rodrigue et al 2001).Green supply management is related to organization's attempts to lessen its effect on the environment by reducing contamination to air, water and land as well as abating energy consumption (Edmonton (2013). The concept of green Supply Chain Management will enable in avant-garde policies for issues related to the overall environment. Environmental certifications, pollution prevention, reverse logistics, life-cycle assessment and design for the environment are the five possible green supply chain management practices (Klassen and Johnson, 2005).It was found in an experimental study considering six components of green supply chain management including eco design, green manufacturing and packaging, environmental participation, green marketing, stock and suppliers that organizations focusing on green logistics were successful players against their competitors(Shang el al., 2010).A newfangled and distinct addition in the retail store sector in Bangladesh is the commencement of superstores. The superstores segment of the country was on a growing trend since the instigation of Agora back in 2001 (Islam et al., 2017). The objective of this study is to have an approximate idea about the extent of implementation of green logistics by various superstores in Bangladesh.

\section{Literature Review:}

As in the quality revolution of the 1980s and the supply chain revolution of the 1990s, it has become clear that the best practices call for integration of environmental management with ongoing operations (SK Srivastava 2007). 
Green supply chain management is gaining increasing interest among researchers and practitioners of operations and supply chain management (SK Srivastava 2007). However it is not just about being environment friendly; it is about good business sense and highest profits. In fact, it is a business value driver and not a cost center (Wilkerson 2005). Some companies addressed environmental management as a good business practices and initiated environmentally friendly is not only about driving cost, but creating value for business ( Wilkerson, 2005) and improving financial performance. (Zhu and Sarkis, 2004).

Sufficient literature exists about various aspects and facets of Green Supply chain management. Comprehensive reviews on green design ( Zhang et al. 1997) production planning and control for remanufacturing ( Bras and McIntosh 1999; Guide 2000; guide et al. 1997a,b). issues in green manufacturing. Sufficient literature also exists in the related areas of green (Zhu and Geng 2001). Earlier works and reviews have a limited focus and narrow perspective. There is not enough aspects and facets Green Supply Chain management. Although Ahi and Searcy (2013) identified 22 different definitions for green Supply Chain management, we identified Green Supply Chain management as "integrating environmental thinking into supply chain managements including product design, material sourcing and selection, manufacturing processes, delivery of the final products to the consumer as well as end of life management of the products after its useful life ( Srivastava 2007)". Companies have realized that integration of environmental management practices across all departments of organization is necessary for the best outcome ( Srivastava, 2007). Such change was a customer-driven process along with pressure from stakeholders and competitors of focal company supply chains ( Seuring et al., 2005). According to Srivastava (2007) Green supply chain management's scope ranges from reactive monitoring of general environmental management programs to more proactive practices implemented through various Rs like Reduce, Re-use, Rework, Refurbish, Reclaim, Recycle, remanufacture, Reverse Logistics, etc. Green retailing constitutes well -elaborated stream of research that explores a range of divergent aspects and issues, from retail sustainability challenges (lles, 2007; Erol et al., 2009), consumer's perception of environmental retailing performance to sustainable consumer behavior (Ytterhus et al., 1999). Kotzab and teller (2005) consider in-store logistics as 'hot topic due to the dominance of store-based retailing. While Reiner et al .(2013) identify ways of improving in store logistics processes for handling dairy products from the incoming dock to the shelves of supermarkets. Holweg et al. (2016) focus more on in-store logistics beyond the point of sale with respect to the economic, ecological and social benefits for retailers, as well as other stakeholder and focus more on prevention of wastage of supply chain resources. Arguments regarding greening in-store processes require companies to appropriately manage their own resources and processes before demanding related actions from their suppliers or customers (Vachon and Klassen, 2006). A growing number of food retailers are concerned about the impact of their business activities on the environment (Piacentini et al., 2000). The retailers implement environmentally responsible activities, mainly at the company level, which are then extended to stores (Jones et al., 2005). Lehner (2015) argues that retail stores are significant contributors to the operationalization of sustainable consumption. Environmental practices that retailers pursue in store include energy efficiency, waste reduction and the use of renewable energy (Lai et al., 2010).

\section{Methodology}

The analytical results are from a sample of 90 superstores in Dhaka city. Information was collected through a predesigned questionnaire. The questionnaire contains questions regarding obedience to environmental rules and regulation, verification of certificates regarding environmental management system, awareness of environmental rules and regulation regarding supply and storage of goods, arrangement of seminar and workshop to make the suppliers aware of greening, organizing tree plantation activities as well as regular meeting of the employees by different outlets or branches. The variables are qualitative in nature. All of them were measured by nominal scores for analytical purpose. Some relevant statistical analyses like Pearson's correlation coefficient, test of significance etc. were performed using SPSS (Statistical Package for Social Science). Significance was determined with pvalue $\leq 0.01$. Mathematically, Pearson's correlation coefficient,

$$
r=\frac{\operatorname{Cov}(x y)}{\sqrt{V(x) V(y)}}=\frac{\frac{1}{n} \sum(x-\bar{x})(y-\bar{y})}{\sqrt{\frac{1}{n} \Sigma(x-\bar{x})^{2} \frac{1}{n} \Sigma(y-\bar{y})^{2}}}=\frac{\sum x y-\frac{\sum x \Sigma y}{n}}{\sqrt{\left[\sum x^{2}-\frac{(\Sigma x)^{2}}{n}\right]\left[\Sigma y^{2}-\frac{(\Sigma y)^{2}}{n}\right]}}=\frac{S P(x y)}{\sqrt{S S(x) S S(y)}}
$$

\section{Results and discussion}

As mentioned earlier, data were collected from 90 superstores via pre-assigned questionnaire. The distribution of the respondents can be visualized through figure 1 . 
35

30

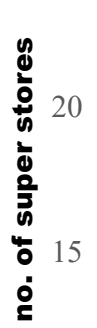

10

5

0

\section{2}

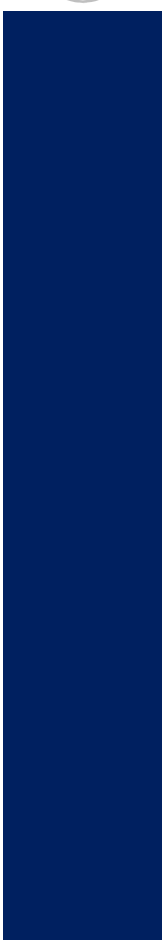

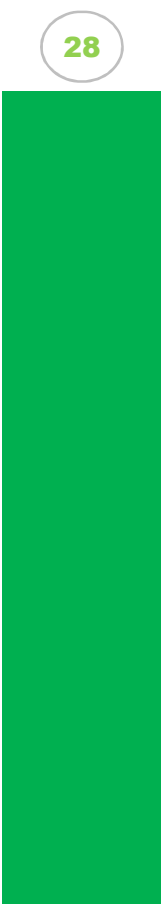
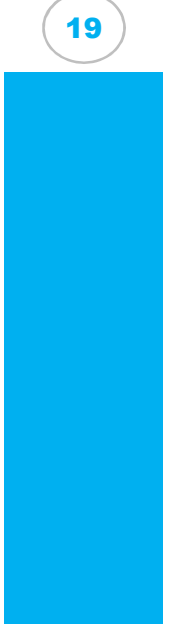

- Shopno

Agora

MeenaBazar

11

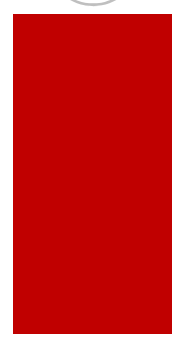

Others

\section{Figure 1: Frequency distribution of the respondents (branches or outlets)}

Shwapno represents the highest number of superstores (32) followed by Agora (28), Meena Bazar (19) and others (11) respectively. In Table 1, we have summarized the information that was collected from different superstores in Dhaka city. The Environment Conservation Rules (1997)is the nationally acknowledged environmental management system standard in Bangladesh to be followed by institutions in different segments of the country to generate and implement their respective policy regarding green logistics. As we can see, most of the superstores(93.3\%) follow the environmental rules and regulation as well as verify certificates of environmental management system (90\%). Also, a large portion of them $(86.7 \%)$ are aware of environmental rules and regulation regarding supply and storage of goods. Around 59\% of them arrange seminar and workshop to make the suppliers aware of greening. Most of the superstores (94.4\%) organize regular meeting of the employees. The only concern is that less than half of them (48.9\%) organize tree plantation activities which is not good enough.

Table 1: Frequency distribution of responses of the respondents

\begin{tabular}{|l|l|l|l|}
\hline & & Frequency & Percentage \\
\hline \multirow{3}{*}{ conformity to environmental rules and regulation } & Yes & 84 & 93.3 \\
\hline \multirow{3}{*}{ Verifying certificates of environmental management system } & No & 6 & 6.7 \\
\hline Awareness of environmental rules and regulation regarding supply & Yes & 81 & 90 \\
\cline { 2 - 4 } and storage of goods & No & 9 & 10 \\
\hline \multirow{3}{*}{ Arranging seminar and workshop to make suppliers aware } & No & 78 & 86.7 \\
\hline \multirow{3}{*}{ Organizing tree plantation activities } & Yes & 53 & 12.3 \\
\hline \multirow{3}{*}{ Organizing regular meeting of the employees } & No & 37 & 58.9 \\
\cline { 2 - 4 } & Yes & 44 & 41.1 \\
\hline
\end{tabular}

In Table 2, results of Pearson correlation analyses are shown. Most of them have shown either weak or negative correlation along with insignificant relationship between them. However, there is an exception in case of arrangement of seminar and workshop with management of greening and tree plantation. These two variables have shown highly significant correlation $(\mathrm{p}$-value $=0.000)$ between them. This is where the policy formation and its application will come into play. The coordinators of the superstores need to focus on managing more constructive 
seminars and workshops to increase the awareness regarding greening and tree plantation.

Table 2: Pearson Correlation analysis of the variables

\begin{tabular}{|c|c|c|c|c|c|c|c|}
\hline & & $\begin{array}{l}\text { Abide by } \\
\text { the rules } \\
\text { and } \\
\text { regulation }\end{array}$ & $\begin{array}{l}\text { Verify the } \\
\text { environmental } \\
\text { certificates of } \\
\text { suppliers }\end{array}$ & $\begin{array}{l}\text { Aware of } \\
\text { rules and } \\
\text { regulation } \\
\text { of supply } \\
\text { and } \\
\text { storage }\end{array}$ & $\begin{array}{l}\text { Arrange } \\
\text { seminar } \\
\text { and } \\
\text { workshop }\end{array}$ & $\begin{array}{l}\text { Manage } \\
\text { greening } \\
\text { and tree } \\
\text { plantation } \\
\text { activities }\end{array}$ & $\begin{array}{l}\text { Arrange } \\
\text { regular } \\
\text { meeting } \\
\text { of the } \\
\text { employees }\end{array}$ \\
\hline \multirow{2}{*}{$\begin{array}{l}\text { Conformity by } \\
\text { the rules and } \\
\text { regulation }\end{array}$} & $\begin{array}{l}\text { Pearson } \\
\text { Correlation }\end{array}$ & 1 & -.089 & .026 & .048 & -.006 & -.065 \\
\hline & Significance & & .404 & .806 & .651 & .956 & .544 \\
\hline \multirow{2}{*}{$\begin{array}{l}\text { Verify the } \\
\text { environmental } \\
\text { certificates of } \\
\text { suppliers }\end{array}$} & $\begin{array}{l}\text { Pearson } \\
\text { Correlation }\end{array}$ & -.089 & 1 & .196 & -.053 & -.119 & -.081 \\
\hline & Significance & .404 & & .064 & .622 & .266 & .449 \\
\hline \multirow{2}{*}{$\begin{array}{l}\text { Aware of rules } \\
\text { and regulation of } \\
\text { supply and } \\
\text { storage }\end{array}$} & $\begin{array}{l}\text { Pearson } \\
\text { Correlation }\end{array}$ & .026 & .196 & 1 & .071 & .122 & .048 \\
\hline & Significance & .806 & .064 & & .507 & .252 & .656 \\
\hline \multirow{2}{*}{$\begin{array}{l}\text { Arrangement of } \\
\text { seminar and } \\
\text { workshop }\end{array}$} & $\begin{array}{l}\text { Pearson } \\
\text { Correlation }\end{array}$ & .048 & -.053 & .071 & 1 & $.365^{* *}$ & -.005 \\
\hline & Significance & .651 & .622 & .507 & & .000 & .959 \\
\hline \multirow{2}{*}{$\begin{array}{l}\text { Manage greening } \\
\text { and tree plantation } \\
\text { activities }\end{array}$} & $\begin{array}{l}\text { Pearson } \\
\text { Correlation } \\
\end{array}$ & -.006 & -.119 & .122 & $.365^{* *}$ & 1 & -.054 \\
\hline & Significance & .956 & .266 & .252 & .000 & & .614 \\
\hline \multirow{2}{*}{$\begin{array}{l}\text { Arrangement of } \\
\text { regular meeting of } \\
\text { the employees }\end{array}$} & $\begin{array}{l}\text { Pearson } \\
\text { Correlation }\end{array}$ & -.065 & -.081 & .048 & -.005 & -.054 & 1 \\
\hline & Significance & .544 & .449 & .656 & .959 & .614 & \\
\hline
\end{tabular}

\section{Conclusion}

It can be concluded from the outcomes of the study that to a greater level, bulk of the superstores in Dhaka engage the subsequent green logistics practices: obedience to environmental rules and regulation, verification of certificates regarding environmental management system, awareness of environmental rules and regulation regarding supply and storage of goods, arrangement of seminar and workshop to make the suppliers aware of greening, organizing tree plantation activities as well as regular meeting of the employees towards the saving of the environment.

\section{References}

1. Bras, B. and McIntosh, M.W. (1999). Product, process, and organizational design for remanufacture - an overview of research. Robotics and Computer-Integrated Manufacturing, 15, 167- 178

2. Erol, I., Cakar, N., Erel, D. and Sari, R. (2009), "Sustainability in the Turkish retailing industry", Sustainable Development, Vol. 17 No. 1, pp. 49-67.

3. Guide, V.D.R. and Srivastava, R. (1997a). Buffering from material recovery uncertainty in a recoverable manufacturing environment. Journal of the Operational Research Society, 48, 519-529

4. Guide, V.D.R. and Srivastava, R. (1997b). Repairable inventory theory: models and applications. European Journal of Operational Research, 102, 1-20.

5. Holweg, C., Teller, C. and Kotzab, H. (2016), "Unsaleable grocery products, their residual value and instore logistics”, International Journal of Physical Distribution \& Logistics Management, Vol. 46 Nos 6/7, pp. 634658.

6. Iles, A. (2007), "Seeing sustainability in business operations: US and British food retailer experiments with accountability", Business Strategy and the Environment, Vol. 16 No. 4, pp. 290-301.

7. Islam et al. (2017). "An Analysis of Customers' Satisfaction of Super Markets in Bangladesh" .International Journal of Research in Business, Economics and Management. Volume.1, Issue 3, pp. 203-220. http://www.ijrbem.com/doc/31.pdf (accessed on 10 October 2018).

8. Jones, P., Comfort, D. and Hillier, D. (2005), "Retailers and sustainable development in the UK", International Journal of Retail \& Distribution Management, Vol. 33 No. 3, pp. 207-214.

9. Klassen, Robert \& Fraser Johnson, P. (2004). "The Green Supply Chain”. Oxford University Press.

10. Kotzab, H. and Teller, C. (2005), "Development and empirical test of a grocery retail instore logistics model", British Food Journal, Vol. 107 No. 8, pp. 594-605. 
11. Lai, K-h., Cheng, T.C.E. and Tang, A.K.Y. (2010), "Green retailing: factors for success”, California Ma Lehner, M. (2015), "Translating sustainability: the role of the retail store", International Journal of Retail \& Distribution Management, Vol. 43 Nos 4/5, pp. 386-402. management Review, Vol. 52 No. 2, pp. 6-31

12. Piacentini, M., MacFayden, L. and Eadie, D. (2000), "Corporate social responsibility in food retailing", International Journal of Retail \& Distribution Management, Vol. 28 No. 11, pp. 459-469.

13. Reiner, G., Teller, C. and Kotzab, H. (2013), “Analyzing the efficient execution of in-store logistics processes in grocery retailing - the case of dairy products", Production and Operations Management, Vol. 22 No. 4, pp. 924-939.

14. Rodrigue et al. (2001). "The Handbook of Logistics and Supply Chain management", Handbook in Transport \#2, London: Pergamon/Elsevier.

15. Seuring, S., Müller, M., Westhaus, M., Morana, R., 2005. Conducting a literature review the example of sustainability in supply chains. In: Kotzab, H., Seuring, S., Müller, M., Reiner, G. (Eds.), Research Methodologies in Supply Chain Management, pp. 91-106

16. Shang et al. (2010). "Taxonomy of green supply chain management capability among electronics-related manufacturing firms in Taiwan".Journal of Environmental Management.https://doi.org/10.1016/j.jenvman.2010.01.016(accessed on 10 October 2018).

17. Srivastava, S.K., 2007. Green supply-chain management: a state-of-the-art literature review. Int. J. Manag. Rev. 9 (1), 53-80.

18. Vachon, S. and Klassen, R.D. (2006), "Extending green practices across the supply chain: the impact", International Journal of Operations \& Production Management, Vol. 26 No. 7, pp. 795-821.

19. Wilkerson, T. (2005). Can One Green Deliver Another? Harvard Business School Publishing Corporation (available at: http://www.supplychainstrategy.org/).

20. Ytterhus, B.E., Arnestad, P. and Lothe, S. (1999), "Environmental initiatives in the retailing sector: an analysis of supply chain pressures and partnerships", Eco Management and Auditing, Vol. 6 No. 4, pp. 181188.

21. Zhang, H.C., Kuo, T.C., Lu, H. and Huang, S.H. (1997). Environmentally conscious design and manufacturing: a state-of-the-art survey. Journal of Manufacturing Systems, 16, 352- 371

22. Zhu, Q. and Geng, Y. (2001). Integrating environmental issues into supplier selection and management. Greener Management International, 35, 27-40. 